\title{
The Impact of Regional Autonomy Policy for Economic Growth in East Java
}

\author{
Wahyu Kurniana, Wahyu Kurniani, Irvan Sepfiandy, Evan Gyovani \\ Faculty of Economics, Universitas Negeri Malang \\ Email:wahyukurniana23@gmail.com
}

Received: June 17, 2017; Accepted: August 12, 2017; Published: November 3, 2017 Permalink/DOI: http://dx.doi.org/10.17977/um002v9i22017p224

\begin{abstract}
This study aims to determine the effect of local revenue, general allocation funds and special allocation funds to local spending and economic growth as well as to find out the possibility of Flypaper Effect on District/City shopping in East Java Province. The population in this study is all districts/cities located in East Java Province. Data analysis was performed by panel data regression using Eviews 8 and Microsoft Excel 2010 program. The results of this study indicate that local revenues, general allocation funds, and special allocation funds have a positive and significant impact on district/city expenditure in East Java. Local revenues, general allocation funds, and special allocation funds have a positive and significant impact on the economic growth of districts/cities in East Java Province. While variable of regional expenditure has negative and significant influence on economic growth of district/city in East Java Province. Local revenues, general allocation funds and special allocation funds indirectly through regional expenditures on district economic growth in East Java Province are negative and regional expenditures are not proven to be intermediate variables. Value of Coefficient of General Allocation Fund and Special Allocation Fund is bigger than the value of the original revenue coefficient so that it can be said that there has been Flypaper Effect on the expenditure of District/City in East Java Province in 2010-2014.
\end{abstract}

Keywords: Economic Growth, Regional Autonomy, Flypaper Effect JEL Classification: R11, R58

\section{INTRODUCTION}

National development is one effort to realize the goal of society that is fair and prosperous welfare. In line with these objectives, various development activities are directed to equitable development into each region, Especially areas that tend to still have weaknesses in revenue, One of them with the policy of regional autonomy. With the enactment of regional autonomy, local governments are required to be more independent in managing local recipients intended for the restructuring process of regional development. Therefore, since the enactment of Law no. 32 of 2004 on Regional Government, and Law no. 33 of 2004 on Fiscal Balance between the Central Government and Local Government has placed regional autonomy intact in districts and municipalities. With the law is expected local governments are able to solve local problems in managing the government and local finances in order to improve the welfare of the community which will have an impact on regional economic growth. 
East Java is one of the regions that is given the authority to manage and manage their own households. East Java as the center of economic growth in eastern Indonesia has a declining economic growth rate, from 2010 to 2014, where in 2010 the economic growth rate of $6.68 \%$, and gradually decreased until 2014 at $5.86 \%$. This indicates that East Java with a high fiscal capacity and supported by the potential of its resources has not been able to maximize its profits to encourage an increase in the rate of economic growth. Bagianto (2015) states that the increase and decline of regional economic growth is determined by government spending. East Java provincial government spending increased from 2010 to 2013, amounting to $\mathrm{Rp} 6,179,313, \mathrm{Rp} 7,774,107, \mathrm{Rp} 10,982,257, \mathrm{Rp} 12,670,706$, respectively, but economic growth in East Java experienced fluctuating conditions from 2010 to 2014.

Law no. 33 of 2004 on Fiscal Balance between the Central Government and Local Government, states that the funding sources of the implementation of local government consist of local revenues, equity funds, and other legitimate income. Balance funds or transfer funds consist of general allocation funds, special allocation funds, and Revenue Sharing Fund. All these funding sources have their respective contributions to local governments for regional expenditures.

The problems that occur today, local governments are too dependent on the general allocation of funds to finance capital expenditure and development without optimizing the potential of the region. It is this fact that leads to asymmetric behavior on local government. To see if there is any indication of inefficiency in the transfer fund, it can be seen from the government expenditure response which is better known as Flypaper Effect.

The results of research conducted by Masdjojo \& Sukartono (2009) stated that in the districts/cities in Central Java experienced a flypaper effect is proven or accepted, ie the response of regional expenditure is still greater due to the balancing funds especially from the component of general allocation fund. The results of this research are similar but the results are different, ie research conducted by Mentayani et al. (2012), which states that there is no flypaper effect on the regional finance of regency/city government in South Kalimantan Province in 2010. The results of this diverse research that encourage researchers to conduct research whether there is a flypaper effect on the regional shopping of East Java Provincial Government.

Based on these issues, a review of the independence of local governments in managing their own areas is necessary. So the purpose of this study is to determine the effect of local revenue, general allocation funds and special allocation funds to regional expenditure and economic growth and to determine the possibility of Flypaper Effect in local spending in East Java Province.

\section{LITERATURE REVIEW Regional Autonomy}

Law No. 32 of 2004 states that regional autonomy is the right, authority and obligation of autonomous regions to regulate and manage their own governmental affairs and the interests of local communities in accordance with the laws and regulations. Provision of regional autonomy to the region is based on the principle of decentralization in the form of broad autonomy, real, and responsible.

Implementation of regional autonomy, in addition to constitutional mandate, is also an objective requirement in the administration of the current 
government. The centralistic pattern of government in the past is no longer appropriate because in addition to inefficient, expensive, also not in accordance with the development of community life is improved and more advanced because of internal and external factors (Darise, 2006).

\section{District Own Source Revenue}

The District Own Source Revenue of the region is income earned by the area collected according to the local regulations in accordance with the laws and regulations. Local revenues as a source of local revenue need to be improved in order to bear some of the burden required for the implementation of government and development activities that increase annually so that independent autonomy outside, real, and responsible can be implemented (Darise, 2006).

According to Law No. 33 of 2004, District Own Source Revenue is the Regional Revenue derived from the results of Regional Taxes, Regional Retributions, the result of separated regional wealth management, and Other Original Regional, which aims to provide flexibility to the Region in digging Funding in the implementation of regional autonomy as a manifestation of the principle of Decentralization.

District Own Source Revenue aims to authorize local governments to fund the implementation of regional autonomy in accordance with the potential of the region as a manifestation of decentralization. Therefore, local revenue must be sought to always increase, this is because local revenue is used to finance expenditure or regional expenditure in order to improve the welfare and provide services to the community one of them through capital expenditure.

The higher the original revenue of the region, the level of regional fiscal dependence on the center decreases. Furthermore, the region is more flexible and flexible in planning budget allocations in accordance with its economic agenda. Through regional expenditure, local revenue as a source of regional financing is expected to create a number of new economic activities for the community. Through regional expenditure, local revenue as a source of regional financing is expected to create a number of new economic activities for the community. With the increase of economic activity in the community, there will be an increase in the amount of output of goods and services followed by an increase in the money supply in terms of spending by the local government. Furthermore, it will increase the value of Gross Domestic Regional Product and the level of community welfare. With the increase of Gross Domestic Regional Product, it will increase local government revenue to finance development programs. This will encourage the improvement of local government services to communities that are expected to increase productivity.

\section{Balancing Funds}

Since the decentralization system has been implemented with the regional autonomy system, transfer funds to regions are allocated one of them in the form of balancing funds. Balancing funds are funds transferred by the central government to local governments in the form of general allocation funds and special allocation funds in order to reduce the gap between regions in accordance with their respective rights (Suparmoko, 2011: 336). 
The General Allocation Fund is a block grant given to all districts and cities for the purpose of filling the gap between capacity and fiscal needs and distributed with a formula based on certain principles that generally indicate that poor and backward areas should receive more than rich areas (Kuncoro, 2014).

The proportion of general allocation funds between provincial and district/municipal districts is set based on the balance of authority between provinces and districts/municipalities. The government formulates the formula and calculation of general allocation funds with due consideration of the board in charge of providing advice and consideration of the policy of regional autonomy. The results of calculation of general allocation funds per province, district, and city are determined by presidential decree (Muti'ah, 2017).

The general allocation fund is one of the important components in the allocation of balancing funds. The total amount of general allocation funds shall be at least 26 percent of the Net Domestic Revenue stipulated in the Indonesian Budget. The General Allocation Fund for an area is allocated on the basis of a fiscal gap and a basic allocation or referred to as a fiscal gap. A regional Fiscal Gap is a difference between fiscal needs and the fiscal capacity of the area (Kuncoro, 2014: 65). The proportion of General Allocation Fund between provinces and districts/municipalities is determined based on the balance of authority between provinces and districts. For regions with large fiscal potential but small fiscal needs will obtain a relatively small allocation of General Allocation Funds. Conversely, the regions with little fiscal potential but large fiscal needs will receive a relatively large allocation of General Allocation Funds as well.

While the Special Allocation Funds according to Law no. 33 of 2004 are funds sourced from the Indonesian Budget allocated to a particular Region with the aim of assisting in funding special activities which are regional affairs and in accordance with national priorities. A special allocation fund is intended to assist in financing special activities in a particular Region which is a Regional affair and in accordance with national priorities, in particular, to finance the basic public service facilities and infrastructure which have not reached a certain standard or to encourage the acceleration of regional development.

The allocation of the Special Allocation Fund is more focused on investment activities in the development, procurement and improvement of physical facilities and infrastructure with long economic life, including the provision of supporting physical facilities, and excluding equity participation. Unlike the General Allocation Fund, the utilization of the Special Allocation Fund follows the various regulations of the central government, so that the regions can not flexibly and flexibly process the funds. With the focus of allocation to physical spending on infrastructure facilities and infrastructures, the fixed assets of the Special Allocation Fund will be the basic capital in carrying out economic activities that lead to increased output and community welfare. So it can be said that the allocation of special funds can encourage regional economic growth.

\section{The Linkage of Regional Expenditure to Economic Growth}

According to Masdjojo \& Sukartono (2009), Regional expenditure is all expenditure from regional public treasury accounts that reduce the equity of funds and is a regional obligation within a budget year and will not be repaid by the region. Government expenditure by Sukirno (2010); Sitaniapessy (2013) is part of fiscal 
policy, which is a government action to regulate the economy by determining the amount of government revenue and expenditure annually, which is reflected in the Indonesian Budget documents for national and regional budgets for regional or regional. The objective of this fiscal policy is to improve the efficiency and effectiveness of regional expenditures, in particular to promote economic growth that has become the task and function of the region.

Government spending will support economic growth if the government is able to create the conditions under which the allocation of government expenditures to overall output levels can be used to provide public goods used as competitive inputs of production. Government spending is used to provide public services to increase public welfare, such as the provision of good infrastructure. With the availability of good infrastructure is expected to create efficiency and effectiveness in various sectors, and public productivity is expected to become higher and in turn there is an increase in economic growth.

Regarding government expenditures, the Law of Expanding State Activity (Wagner's Law) is referred to as Adolf Wagner's Law, where economic growth is a fundamental factor determining the growth of the public sector including government spending and consumption (Ma'aruf \& Wihastuti, 2008). Wagner states that in an economy if per-capita income increases then the relative expenditure of government will increase mainly due to the government must regulate the relationships that arise in society, law, education, recreation, culture and so forth.

Government expenditures are used to provide public servants to the public for increased public prosperity, such as the provision of good infrastructure. With the availability of good infrastructure is expected to create efficiency and effectiveness in various sectors, community productivity is expected to become higher and in turn, there is an increase in economic growth.

\section{Flypaper Effect}

The term Flypaper effect was first introduced by Courant, Gramlich, and Rubinfeld in 1979 to articulate Arthur Okun's 1930 thinking stating "Money Sticks Where It Hits". So far, there has been no word "Flypaper Effect" in Indonesian so that the word is written as it is without being translated. Gramlich along with Courant and Rubinfeld sought an explanation for the phenomenon that inappropriate grants stimulate more local spending per dollar grant than income that goes to private citizens in the community. In this case, the finding is that grants from the central government to local governments will increase the local government's expenditures by an amount larger than local revenue increases.

Flypaper Effect is a condition where the stimulus to regional expenditure caused by the change in the amount of transfers (unconditional grants) from the central government is greater than that caused by changes in regional income (Iskandar, 2012; Sumarsono \& Rahmawati, 2017).

\section{METHOD}

\section{Data Analysis Method}

The analytical method that will be used to analyze the influence of local revenue, general allocation fund and special allocation fund to regional expenditure and economic growth and flypaper effect analysis of districts in East Java 2010- 
2014 are using pooled data system with computer program Eviews 8 And Microsoft Excel 2010. Here are the methods used in analyzing the data in this study:

\section{Path Analysis}

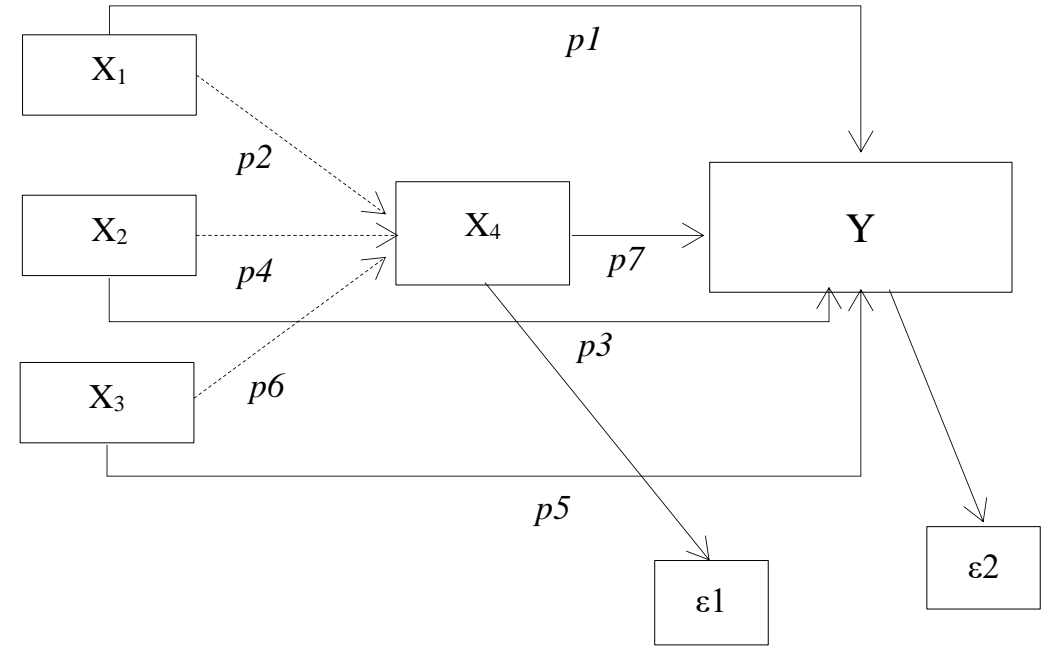

Figure 1. Path Analysis Model

Based on the figure 1 can be made two regression equations are:

$X_{4 i t}=\alpha+\beta_{1} X_{1 i t}+\beta_{2} X_{2 i t}+\beta_{3} X_{3 i t}+\varepsilon_{1}$

$Y=\alpha+\beta_{1} X_{1 i t}+\beta_{2} X_{2 i t}+\beta_{3} X_{3 i t}+\beta_{4} X_{4 i t}+\varepsilon_{2}$

Information:

Y = Economic Growth

$\alpha \quad=$ Constanta

$\beta=$ Regression Coefficient

$\mathrm{X}_{1} \quad=$ Local Revenue

$\mathrm{X}_{2} \quad=$ General Allocation Funds

$\mathrm{X}_{3} \quad=$ Special Allocation Funds

$\mathrm{X}_{4} \quad=$ Regional Expenditure

$\varepsilon \quad=$ Erorr

\section{Flypaper Effect Analysis}

In this study, the model used to analyze the data or test the regional expenditure on the district/city in East Java Province experienced flypaper effect or not by taking the test result from structural 1, where:

$\mathrm{X}_{4}=\alpha+\beta_{1} X_{1 i t}+\beta_{2} X_{2 i t}+\beta_{3} X_{3 i t}+\varepsilon_{1}$

The possibility of a flypaper effect can be seen based on the following conditions:

1) The value of the coefficient of general allocation funds and special allocation funds is greater than the value of the local revenue coefficient, and both have a significant effect on local expenditure. 
2) The value of the local revenue coefficient is greater than the value of the coefficient of general allocation funds and special allocation funds, but no significant effect on regional expenditure.

\section{RESULT AND DISCUSSION}

\section{Path Analysis}

Based on the results of research can be found the relationships among variables research, which is the path coefficient in this study.

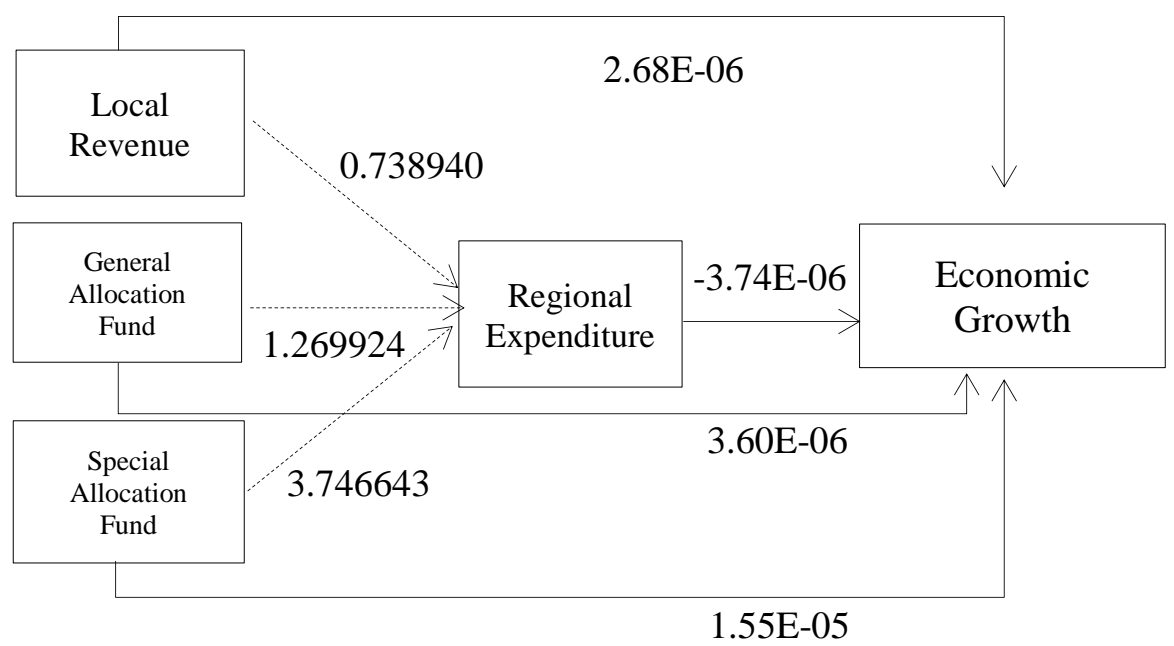

Figure 2. Diagram of Research Path Analysis

Based on figure 2 can be calculated direct influence and indirect influence between variables as follows.

Table 1. Summary of Intermediate Variables Test

\begin{tabular}{|c|c|c|c|c|c|c|}
\hline No & Variable & Direct & Indirect & Total & $\begin{array}{c}\text { Influence } \\
\text { Criteria }\end{array}$ & Conclusion \\
\hline 1 & $\begin{array}{l}\text { Local } \\
\text { Revenue }\end{array}$ & $\begin{array}{l}2,68 \mathrm{E}- \\
06\end{array}$ & $\begin{array}{l}-2,76 \mathrm{E}- \\
06\end{array}$ & $\begin{array}{l}-8,35 \mathrm{E}- \\
08\end{array}$ & $\begin{array}{l}\text { Direct } \\
\text { Effect }> \\
\text { Indirect } \\
\text { Effect }\end{array}$ & $\begin{array}{l}\text { Regional expenditure } \\
\text { variable is not as an } \\
\text { intermediate variable }\end{array}$ \\
\hline 2 & $\begin{array}{l}\text { General } \\
\text { Allocation } \\
\text { Fund }\end{array}$ & $\begin{array}{l}3,60 \mathrm{E}- \\
06\end{array}$ & $\begin{array}{l}-4,75 \mathrm{E}- \\
06\end{array}$ & $\begin{array}{l}-1,15 \mathrm{E}- \\
06\end{array}$ & $\begin{array}{l}\text { Direct } \\
\text { Effect }> \\
\text { Indirect } \\
\text { Effect }\end{array}$ & $\begin{array}{l}\text { Regional expenditure } \\
\text { variable is not as an } \\
\text { intermediate variable }\end{array}$ \\
\hline 3 & $\begin{array}{l}\text { Special } \\
\text { Allocation } \\
\text { Fund }\end{array}$ & $\begin{array}{l}1,55 \mathrm{E}- \\
05\end{array}$ & $\begin{array}{l}-1,40 \mathrm{E}- \\
05\end{array}$ & 1,49E-06 & $\begin{array}{l}\text { Direct } \\
\text { Effect> } \\
\text { Indirect } \\
\text { Effect }\end{array}$ & $\begin{array}{l}\text { Regional expenditure } \\
\text { variable is not as an } \\
\text { intermediate variable }\end{array}$ \\
\hline
\end{tabular}

Source: Data processed, 2017

\section{Coefficient of Determination $\left(\mathbf{R}^{2}\right)$}

$\mathrm{R}$ Square value is said to be good if its value is above 0.5 or close to 1 , since $\mathrm{R}$ Square value ranges from $0<\mathrm{R}^{2}<1$. From the results of analysis on the structural, 
I obtained value Test $\mathrm{R}^{2}$ of 0.9820 or $98.20 \%$. While for structural II obtained value of $\mathrm{R}^{2}$ equal to 0,4552 or $45,52 \%$.

\section{Hypothesis Test}

The t-test is used to determine whether there is influence of each independent variable to the dependent variable tested at the 0.05 significance level.

\section{Table 2. $t$ Test for Structural I}

\begin{tabular}{lcccc}
\hline \multicolumn{1}{c}{ Variable } & Coefficient & t-Statistic & Prob. & $\begin{array}{c}\text { Decision Hypothesis } \\
\text { Testing }\end{array}$ \\
\hline C & 46206.10 & 0.905464 & 0.3667 & - \\
Local Revenue & 0.738940 & 11.89310 & 0.0000 & Significant \\
General Allocation Fund & 1.269924 & 19.72043 & 0.0000 & Significant \\
Special Allocation Fund & 3.746643 & 7.998555 & 0.0000 & Significant \\
\hline SErce:
\end{tabular}

Source: data processed, 2017

From table 2 it is known that the local revenue variable, general allocation funds, and special allocation funds partially have significant effect on regional expenditure variable.

Table 3. $t$ Test for Structural II

\begin{tabular}{lcccc}
\hline \multicolumn{1}{c}{ Variable } & Coefficient & t-Statistic & Prob. & $\begin{array}{c}\text { Decision } \\
\text { HypothesisTesting }\end{array}$ \\
\hline $\mathrm{C}$ & 6.999621 & 12.77253 & 0.0000 & - \\
Local Revenue & $2.68 \mathrm{E}-06$ & 2.880790 & 0.0046 & Significant \\
General Allocation Fund & $3.60 \mathrm{E}-06$ & 2.744834 & 0.0068 & Significant \\
Special Allocation Fund & $1.55 \mathrm{E}-05$ & 2.576025 & 0.0110 & Significant \\
Regional Expenditure & $-3.74 \mathrm{E}-06$ & -4.263932 & 0.0000 & Significant \\
\hline
\end{tabular}

Source: data processed, 2017

From table 3 it is known that the original revenue variable, general allocation funds, special allocation funds and regional expenditures partially have a significant effect on the variable of economic growth.

\section{Flypaper Effect Analysis}

Based on the result of structural regression I known the regression equation pooled data as follows.

$$
X_{4}=46206,10+0,7389 X_{1 i t}+1,2699 X_{2 i t}+3,7466 X_{3 i t}+\varepsilon_{1}
$$

The value of the local revenue coefficient $\left(\mathrm{X}_{1}\right)$ of 0.7389 is smaller than the value of coefficient of general allocation fund $\left(\mathrm{X}_{2}\right)$ of 1.2699 and smaller than the value of coefficient of special allocation fund $\left(\mathrm{X}_{3}\right)$ of 3.7466. And these three variables have a significant effect on regional expenditure because each variable has a probability value of 0.0000 smaller than 0.05 . Thus it can be stated that the effect of general allocation funds and special allocation funds is greater than the original revenues for regional spending on districts/cities in East Java Province, so it has experienced flypaper effect. 


\section{The Effect of Local Revenue, General Allocation Fund and Special Allocation Fund to Regional Expenditure of District/City in East Java Province}

The coefficient value of the local revenues, general allocation fund and special allocation fund respectively of $0.7389,1.2699$, and 3.7466 indicates that the variable has a positive effect on regional expenditure. Increasing local revenues, general allocation funds, and special allocation funds can increase regional expenditure.

This is because local revenues are the main source of income for local government revenues from sources of wealth within the region itself. Local revenues as an indicator for assessing the independence of a region and a benchmark of government success in terms of execution of government tasks, development, and delivery of public services to the community, the District / City Government in East Java Province is required to continue to explore potential sources Which originated from its own territory in order to increase its own original income. The greater the value of local revenue derived from the greater the stimulus to increase regional expenditure.

This is also because the general allocation fund is the most important form of transfer in the allocation of balancing funds (Abdillah \& Mursinto, 2016). General allocation funds can increase regional expenditure as each general allocation fund received by the local government is intended to fund regional operational needs. With the increase of regional expenditure is expected to improve public services by local government to the community.

It is also because special allocation funds are funds sourced from APBN revenues allocated to certain regions with the aim of assisting in funding specific activities which are regional affairs and in accordance with national priorities that are regional affairs. The utilization of special allocation funds is directed to development investment activities, procurement, upgrading and improvement of physical infrastructure with long economic life, including the provision of supporting physical facilities. With the allocation of special allocation, funds are expected to affect the allocation of regional expenditures, especially capital expenditure because the special allocation funds tend to increase fixed assets owned by the government to improve public services so that the welfare of the community will increase.

The results also reinforce the incrementalism budgetary theoretical basis, that the allocation of local budgets will adjust to the increase/decrease in the amount of income budget received by the regions

\section{The Effect of Local Revenue, General Allocation Fund, Special Allocation Fund and Regional Expenditure on Economic Growth of District/City in East Java Province}

The coefficient value of 2.68E-06 indicates that the local revenue of the region has a positive effect on economic growth. Increased local revenue can increase economic growth. This is because the high level of local revenue is high, local governments are more able to optimize the potential of the region's local revenue because the local revenue is the revenue earned area that is levied according to local regulations in accordance with the legislation. The regional financial policy is directed to increase local revenues as a primary source of local revenue that can be used in implementing governance and regional development in accordance with 
their needs to minimize the dependence on obtaining funds to the government. The higher the local revenue the more the economic growth rate increases. This is because local taxes and levies are returned to the community to develop and grow the regional economy.

The coefficient value of 3.60E-06 shows that the general allocation fund positively affects economic growth. Increasing general allocation funds can increase economic growth. This is because the role of general allocation funds is very significant because regional expenditure in districts/cities in East Java Province is more dominated by a number of general allocation funds than the local revenue. The allocation of general allocation funds is not much different from the allocation of local revenues used to finance infrastructure development and infrastructure facilities by local governments, which will have an impact on economic growth.

The coefficient value of $1.55 \mathrm{E}-05$ indicates that the special allocation fund positively affects economic growth. Increased special allocation funds can increase economic growth. This is because special allocation funds are funds derived from APBN allocated to regions to finance certain needs, such as being used to cover public service gap between regions by giving priority to education, health, infrastructure, marine and fishery, agriculture, government infrastructure Regions, and the environment.

The coefficient value of -3.74E-06 indicates that regional expenditure negatively affects economic growth. High regional spending does not necessarily reflect an increase in economic growth. This suggests that this study is inconsistent with the theory that every expenditure issued can increase economic growth. The large and increasing amount of regional expenditure annually can not increase economic growth. This is because the proportion of regional expenditure issued by local governments is more used to finance expenditures such as personnel expenditure than is used to finance productive expenditures such as capital expenditures. The total development of district/city expenditure in East Java shows that personel expenditure is more dominant than other expenditures. Where personnel expenditure exceeds $50 \%$ of total regional expenditure annually. While capital expenditure is only $15 \%$ to $20 \%$ of the total regional expenditure.

\section{Flypaper Effect Analysis at District/City in East Java Province}

The result of comparison of coefficient value of local revenues, general allocation fund, and special allocation fund indicates that there have been flypaper effect at district/city expenditure in East Java Province. This indicates that the level of fiscal dependence of regency/municipal governments in the province of East Java towards the central government is still high, where local governments tend to wait for assistance from the central government compared to managing the resources and potential of the region itself.

The results of this study in accordance with research conducted by Masdjojo and Sukartono (2009) that there has been a flypaper effect on regional expenditure in Central Java. The results of this study are also consistent with the research conducted by Prakoso (2004) where the amount of regional expenditure is more influenced by the general allocation funds received from the central government than the local revenue of the region itself. This indicates that the level of dependence of district/city governments on the central government is still high. 


\section{CONCLUSION}

Local revenue variable, general allocation fund, and special allocation fund influenced positively and significantly to district/city expenditure in East Java Province. The greater the revenue the region gets, the greater the expenditure of the region. Local revenue variable, general allocation fund and special allocation fund influenced positively and significantly to economic growth of district/city in East Java Province. While the variable of regional expenditure has negative and significant influence to economic growth of districts/cities in East Java Province. This indicates that the expenditure of regional expenditure will decrease economic growth that occurs in an area.

The indirect influence of independent variables through the intermediate variables to the dependent variable is the local revenue variable, the general allocation fund and the special allocation fund indirectly through the regional expenditure on the economic growth of districts in East Java Province is negative and regional expenditure is not proven as a variable Intermediaries. This is due to the direct effect of local revenues, general allocation funds and special allocation funds on economic growth greater than indirect revenue by regional expenditure. Regional expenditures of district/city in East Java Province have a flypaper effect, this is because the effect of balancing funds (general allocation funds and special allocation funds) is greater on regional expenditures than on local revenues.

Suggestions of this research are: Local governments should optimize the economic potentials in their regions to increase local revenues used to finance local expenditures for the benefit of their communities through the development of public services and with the regional independence in managing the potential of the region is expected to reduce the dependence of local governments to the central government. Local governments should further increase their capital expenditure to improve public services so it is expected to help foster regional economic growth.

\section{REFERENCES}

Abdillah, K., \& Mursinto, D. (2016). The Effect of Financial Balance Transfer and Regional Own-Source Revenue on Regional Expenditure of Regencies and Municipalities in East Java Province. International Journal of Scientific and Research Publications, 6(5), 26-30.

Bagianto, A. (2015). Pengaruh Belanja Daerah Terhadap Pertumbuhan Ekonomi Daerah Dan Implikasinya Terhadap Pendapatan Asli Daerah. Tesis Dipublikasikan. Bandung: Pascasarjana Magister Akuntansi Universitas Widyatama

Darise, N. (2006). Pengelolaan Keuangan Daerah. Jakarta: Indeks.

Iskandar, I. (2012). Flypaper Effect Pada Unconditional Grant. Jurnal Ekonomi Pembangunan, 13(1), 113-131.

Kuncoro, M. (2014). Otonomi Daerah: Menuju Era Baru Pembangunan Daerah Edisi 3. Jakarta: Erlangga.

Ma'aruf, A., \& Latri, W. (2008). Pertumbuhan Ekonomi Indonesia: Determinan dan Prospeknya. Jurnal Ekonomi dan Studi Pembangunan, 9(1), 44-55.

Masdjojo, G. N., \& Sukartono. (2009). Pengaruh Pendapatan Asli Daerah dan Dana Perimbangan Terhadap Belanja Daerah Serta Analisis Flypaper Effect Kabupaten/Kota Di Jawa Tengah Tahun 2006-2008. Tema, 6(1), 1-15. 
Mentayani, I., Hayati, N., \& Rusmanto. (2012). Flypaper Effect pada Pendapatan

Asli Daerah dan Dana Alokasi Umum terhadap Belanja Daerah pada

Kabupaten/Kota di Kalimantan Selatan. Jurnal Spread, 2(1), 55-64.

Muti'ah. (2017). The Effect of Regional Revenue, Revenue Sharing Fund, General Allocation Fund and Special Allocation Fund on Regional Economic Growth. Research Journal of Finance and Accounting, 8(8), 102-112.

Sadono, S. (2010). Makroekonomi. Teori Pengantar. Edisi Ketiga. PT. Raja Grasindo Perseda. Jakarta.

Sumarsono, H., \& Rahmawati, F. (2017). The Phenomenon Flypaper Effect in

Balanced Funds, Regional Revenue and Surplus Budget Funding of

Economic Growth and Regional Expenditure in Districs/Cities East Java

Province. Journal of Economics and Finance, 8(1), 42-52.

Suparmoko, M. (2011). Keuangan Negara: Dalam Teori dan Praktik Edisi

Keenam. Yogyakarta: BPFE - Yogyakarta.

Undang-Undang Nomor 32 Tahun 2004 Tentang Pemerintah Daerah.

Undang-Undang Nomor 33 Tahun 2004 Tentang Perimbangan Keuangan Antara Pemerintah Pusat dan Pemerintah Daerah. 